\title{
PENILAIAN SIKAP SISWA DALAM PEMBELAJARAN BAHASA INDONESIA OLEH GURU KELAS VII DI SMP NEGERI 1 KOTA BENGKULU
}

\author{
Ise Audina, Susetyo, dan M. Arifin \\ Program Studi Pendidikan Bahasa Indonesia \\ Jurusan Pendidikan Bahasa dan Seni \\ FKIP Universitas Bengkulu \\ Iseaudina82@gmail.com
}

\begin{abstract}
Abstrak
Tujuan penelitian ini untuk mendeskripsikan penilaian sikap dalam pembelajaran Bahasa Indonesia oleh guru kelas VII di SMP Negeri 1 Kota Bengkulu. Jenis penelitian ini adalah kualitatif dengan metode deskriptif. Data dalam penelitian ini adalah pelaksanaan penilaian sikap di kelas, RPP guru, serta dokumen penilaian sikap yang dibuat guru. Sumber data dalam penelitian ini adalah dua orang guru mata pelajaran bahasa Indonesia dan seluruh siswa kelas VII 5 dan VII 8. Teknik pengumpulan data dalam penelitian ini dilakukan melalui tiga langkah, yaitu dokumentasi, observasi, dan wawancara. Penelitian ini menggunakan teknik analisis data model Milles dan Huberman. Hasil penelitian ini menujukkan bahwa Guru Mata Pelajaran Bahasa Indonesia kelas VII di SMPN 1 Kota Bengkulu telah melakukan perencanaan penilaian sikap berdasarkan Kurikulum 2013 dengan mempersiapkan lembar observasi, lembar penilaian diri dan penilaian antar peserta didik. Pelaksanaan penilaian sikap dengan teknik observasi oleh guru Bahasa Indonesia berlangsung secara kontekstual dan terintegrasi saat kegiatan pembelajaran Bahasa Indonesia berlangsung serta pelaksanaan penilaian diri dan penilaian antar peserta didik dilakukan guru satu kali diakhir semester. Pemanfaatan penilaian sikap dengan teknik observasi dilakukan guru langsung setelah mencatat sikap negatif siswa dalam jurnal dengan cara memberikan teguran, nasihat, dan membuat surat perjanjian. Hasil penilaian sikap selama satu semester dilaporkan guru Bahasa Indonesia kepada guru wali kelas.
\end{abstract}

\section{Kata Kunci: Penilaian sikap, kurikulum 2013, pembelajaran Bahasa Indonesia}

\begin{abstract}
The aim of this research is to describe the attitude assessment in learning Indonesian language by teacher of class VII in junior school 1 Bengkulu City. Type of this research is qualitative with descriptive method. The data in this study is the implementation of classroom attitudinal assessment, teacher's RPP and attitudinal assessment documents that was made by the teacher. The Sources of data in this study are two Indonesian language teachers and all students of class VII 5 and VII 8. Data collection techniques in this study were conducted through three steps: documentation, observation, and interviews. This research used data analysis technique model of Milles and Huberman. The results of this study showed that the teachers of Indonesian language subject of VII grade at SMPN 1 Kota Bengkulu have done attitude assessment based on Curriculum 2013 by preparing observation sheet, self-assessment sheet and assessment among students. Implementation of attitude evaluation with observation technique by Indonesian teacher was done contextually and integrated when Indonesian learning activity took place as well as implementation of self-assessment and assessment among students that were conducted by
\end{abstract}


teacher once at the end of semester. Utilization of attitude evaluation with observation technique was done by teacher directly after recorded negative attitude of student in journal by giving reprimand, advice, and making letter of agreement. The result of attitude evaluation during one semester was reported by Indonesian teacher to the homeroom teacher.

\section{Keywords: Attitude Assessment, curriculum of 2013, learning Indonesian language}

\section{PENDAHULUAN}

Kurikulum 2013 merupakan kurikulum penyempurna dari kurikulum sebelumnya yaitu Kurikulum Tingkat Satuan Pendidikan (KTSP), perubahan Kurikulum 2013 ini juga di dasari oleh perubahan dan tuntutan perkembangan zaman. Hadirnya Kurikulum 2013 sebagai pintu pembuka gerbang dunia pendidikan yang mengedepankan pendidikan karakter kepada peserta didik. Kurikulum 2013 merupakan kurikulum berbasis kompetensi dengan tujuan mengarahkan peserta didik menjadi lebih aktif, produktif, inovatif, dan kreatif melalui penguatan sikap, pengetahuan, dan keterampilan. Ketiga aspek kompetensi berupa aspek pengetahuan, sikap dan keterampilan dalam proses pembelajaran dan penilaiannya harus dilaksanakan secara utuh agar peserta didik tidak hanya memiliki kecakapan dalam ilmu pengetahuan, tetapi juga dibekali karakter yang kuat sesuai dengan tujuan pendidikan nasional. Mulyasa (2015: 169) mengungkapkan Keunggulan dari Kurikulum 2013 yang menjadi pembeda dengan Kurikulum sebelumnya, Kurikulum tingkat satuan pendidikan (KTSP) adalah Kurikulum 2013 lebih ditekankan pada aspek afektif dengan penilaian yang ditekankan pada penilaian berbasis kompetensi serta dalam impelementasi kurikulum berbasis kompetensi dan karakter ini, peserta didik tidak lagi banyak menghapal, namun langsung menerapkan ilmu yang di dapat dalam kehidupan nyata karena Kurikulum 2013 dirancang untuk mempersiapkan peserta didik yang memiliki budi pekerti atau karakter yang baik.

Sesuai dengan tujuan pendidikan nasional yang tercantum dalam UU No. 20 Tahun 2003 tentang Sistem Pendidikan Nasional, yaitu "Berkembangnya potensi peserta didik agar menjadi manusia yang beriman dan bertaqwa kepada Tuhan Yang Maha Esa, berakhlak mulia, sehat, berilmu, cakap, kreatif, mandiri, dan menjadi warga negara yang demokratis serta bertanggung jawab". Jadi, pengembangan Kurikulum 2013 dirumuskan berdasarkan kesadaran nyata dan optimisme yang kuat untuk menghasilkan insan manusia Indonesia yang tidak hanya cerdas berpengetahuan dan berketerampilan saja, tetapi juga memiliki sikap atau karakter bertakwa kepada Tuhan Yang Maha Esa dan berakhlak mulia.

Kuriniasih dan Berlin (2014: 8) mengemukakan salah satu keunggulan Kurikulum 2013 adalah pendidikan karakter dan pendidikan budi pekerti yang telah diintegrasikan ke dalam semua program studi atau mata pelajaran, selain itu penentuan nilai bagi siswa bukan hanya didapat dari nilai ujian saja tetapi juga dari nilai kesopanan, religi, praktik, sikap dan nilai. Oleh karena itu, implementasi sikap sesuai Kompetensi Inti satu (KI-1) dan Kompetensi Inti dua (KI-2) serta penilaiannya harus dilakukan oleh pendidik.

Penilaian sikap sesuai dengan Kompetensi Inti satu (KI-1) dan Kompetensi Inti dua (KI-2) berbeda dengan $\mathrm{KI}-3$ dan $\mathrm{KI}$ 4 hal ini karena Kompetensi Inti sikap spiritual dan sikap sosial tidak diajarkan 
melalui materi pelajaran oleh guru di sekolah, tetapi melalui proses pembiasaan dan keteladanan oleh guru. Kompetensi sikap siswa berdasarkan Kurikulum 2013, terjadi secara terintegrasi sebagai efek penyerta selama proses siswa mengikuti pembelajaran. Secara tersurat sikap-sikap yang akan diintegrasikan saat proses pembelajaran dan dinilai dinyatakan dalam KI-1 (spiritual) dan KI-2 (sosial). Sikap-sikap tersebut tidak boleh diabaikan guru karena akan ditagih pada akhir kegiatan pembelajaran, yakni berupa keharusan untuk pengisian buku rapor yang berkaitan dengan aspek sikap siswa.

Berdasarkan perubahan dan ketentuan dalam Kurikulum 2013 yang mengharuskan pendidik untuk mengimplementasikan kompetensi sikap dan melakukan penilaian sikap dalam pembelajaran yang didasarkan pada Kompetensi Inti satu (KI-1) dan Kompetensi Inti dua (KI-2), maka banyak guru yang mengeluhkan kebijakan tersebut. Kesulitan pendidik dalam melakukan penilaian sikap menurut Kemendikbud (2017: 1) adalah sekitar 60\% respon pendidik menyatakan mereka belum dapat merancang, melaksanakan, mengelola, melaporkan, dan memanfaatkan hasil penilaian dengan baik. Kesulitan utama yang dihadapi pendidik adalah merumuskan indikator, menyusun butir-butir instrumen, dan melaksanakan penilaian sikap dengan menggunakan berbagai macam teknik. Selain itu, pendidik menganggap penilaian sikap menyita tenaga dan waktu yang lebih karena pendidik akan lebih repot menilai sikap siswa satu persatu saat pembelajaran.Berdasarkan masalahmasalah yang timbul saat berlakunya Kurikulum 2013 terutama pada aspek Kompetensi sikap dan penilaiannya maka, pemerintah melakukan penyederhanaan aspek penilaian sikap dalam Kurikulum 2013 revisi yang mulai berlaku secara nasional atau seluruh Indonesia tahun ajaran 2016/2017 dengan harapan tidak lagi memberatkan pendidik dan satuan pendidikan dalam mengimplementasikannya di sekolah (Kurniasih dan Berlin, 2016: 7).

Penyederhanaan aspek penilaian sikap oleh guru tersebut adalah, jika pada Kurikulum 2013 versi lama semua guru diwajibkan untuk menilai aspek sosial dan aspek spiritual siswa, maka pada Kurikulum 2013 revisi penilaian aspek sikap spiritual dan sosial dijiwai atau dilakukan oleh guru mata pelajaran Agama dan Pendidikan Pancasila dan Kewarganegaraan (PPKn). Guru mata pelajaran lain tetap melakukan penilaian sikap hanya saja sebagai penguat deskripsi sikap siswa yang akan diberikan kemudian dirumuskan oleh wali kelas. Sesuai dengan Permendikbud No. 24 Tahun 2016, mengenai Kompetensi Inti dan Kompetensi Dasar, diketahui bahwa KD dari $\mathrm{KI}-1$ dan $\mathrm{KI}-2$ hanya terdapat dalam mata pelajaran Agama dan dan Pendidikan Pancasila dan Kewarganegaraan (PPKn), tetapi sesuai dengan tujuan pendidikan nasional yang menghendaki berkembangnya potensi peserta didik agar menjadi manusia yang beriman dan bertaqwa kepada Tuhan Yang Maha Esa, berakhlak mulia, sehat, berilmu, cakap, kreatif, mandiri, dan menjadi warga negara yang demokratis serta bertanggung jawab, maka penilaian sikap dan pelaksanaan kompetensi sikap tetap harus dilakukan oleh semua guru mata pelajaran lain dan terintegrasi saat pembelajaran. Dengan kemudahan yaitu penilaian sikap berupa deskripsi catatan guru saja. Berdasarkan hal tersebut, maka peneliti tertarik untuk mengangkat masalah tersebut menjadi sebuah penelitian dengan judul "Penilaian Sikap Siswa dalam Pembelajaran Bahasa Indonesia oleh Guru Kelas VII di SMP Negeri 1 Kota Bengkulu". 


\section{METODE}

Peneltian ini termasuk penelitian kualitatif dengan metode deskriptif. Metode deskriptif digunakan untuk mendeskripsikan atau menggambarkan suatu keadaan atau fenomena-fenomena apa adanya (Sukmadinata, 2017: 18). Teknik pengumpulan data dalam penelitian ini ditempuh melalui tiga langkah. Langkah tersebut yaitu dokumentasi, observasi, dan wawancara. Sesuai dengan pernyataan dari Sugiyono (2013: 308-309) yang menyatakan teknik pengumpulan data adalah langkah yang paling utama ditempuh dalam penelitian melalui observasi, interview, koesioner, dokumentasi, dan gabungan keempatnya. Teknik pengumpulan data dengan cara observasi dilakukan peneliti untuk melihat pelaksanaan penilaian sikap oleh guru dengan cara observasi, penilaian diri, dan penilaian antar teman. Teknik pengumpulan data dengan cara dokumentasi dilakukan peneliti melalui pencermatan dokumen RPP, jurnal sikap siswa, lembar penilaian diri, dan lembar penilaian antar teman. Teknik pengumpulan data dengan wawancara dilakukan peneliti untuk menggali informasi lebih mendalam kepada dua orang guru bahasa Indonesia kelas VII di SMP Negeri 1 Kota Bengkulu.

\section{HASIL PENELITIAN DAN PEMBAHASAN}

Penilaian sikap siswa dalam pembelajaran Bahasa Indonesia oleh guru kelas VII di SMP Negeri 1 Kota Bengkulu dilaksanakan melaui tiga tahapan yaitu perencanaan penilaian sikap, pelaksanaan penilaian sikap, dan tindak lanjut hasil penilaian sikap.

\section{Perencanaan Penilaian sikap}

Guru mata pelajaran Bahasa Indonesia di SMP Negeri 1 Kota Bengkulu melakukan perencanaan penilaian sikap berdasarkan Kurikulum 2013 sesuai dengan panduan penilaian dari Kemendikbud. Perencanaan yang dilakukan guru diawali dengan mempersiapkan jurnal sikap, memperbanyak lembar penilaian diri dan lembar penilaian antar teman yang telah disusun pihak sekolah, kemudian guru menjadwalkan pelaksanaan penilaian diri dan penilaian antar teman yang dilakukan satu kali persemester yaitu pada akhir materi pembelajaran. Jurnal sikap yang dibuat guru berdasarkan panduan Kemendikbud dalam buku "Panduan Penilaian oleh Pendidik dan Satuan Pendidikan untuk Sekolah Menengah Pertama Edisi Revisi 2017" jurnal sikap tersebut termasuk ke dalam bentuk lembar observasi terbuka di mana guru tidak membuat dan menentukan indikator sikap yang akan dinilai. Jurnal yang dibuat guru merupakan instrumen utama guru dalam menilai sikap siswa dan digunakan untuk memantau serta mencatat perkembangan sikap siswa secara alami dan terintegrasi serta secara kontekstual selama kegiatan pembelajaran bahasa Indonesia berlangsung. Jurnal sikap yang dibuat guru berdasarkan panduan dari Kemendikbud dengan komponen jurnal yang terdiri dari nomor, hari dan tanggal, nama siswa, catatan prilaku siswa, butir sikap (spiritual dan sosial), tanda tangan, dan tindak lanjut. Jumlah tabel pada jurnal dibuat guru tidak terbatas tergantung kepada munculnya sikap negatif siswa saat kegiatan pembelajaran berlangsung.

Perencanaan penilaian sikap juga dilakukan guru bahasa Indonesia kelas VII SMP Negeri 1 Kota Bengkulu dengan mencantumkan teknik penilaian sikap dalam kegiatan penilaian di RPP yang dibuat guru. Penilaian sikap dalam RPP dibuat guru dengan tiga teknik penilaian yaitu jurnal sikap disertai dengan rubik, penilaian diri, dan penilaian antar teman. Jurnal sikap dalam RPP guru berupa tabel penilaian, sedangkan penilaian diri dan penilaian antar teman berupa kolom ceklis 
penilaian sikap yang berisikan sejumlah indikator sikap spiritual dan sikap sosial.

\section{Pelaksanaan Penilaian Sikap}

Pelaksanaan penilaian sikap yang dilakukan guru bahasa Indonesia kelas VII di SMP Negeri 1 Kota Bengkulu dilakukan dengan tiga teknik penilaian yaitu penilaian dengan observasi, penilaian diri dan penilaian antar teman. Kegiatan penilaian sikap dengan teknik observasi dilakukan oleh guru saat proses kegiatan belajar mengajar ketika muncul sikap negatif siswa secara alami saat kegiatan pembelajaran berlangsung, maka guru langsung melakukan penilaian dengan mencatat sikap negatif siswa tersebut ke dalam jurnal sikap yang sudah dipersiapkan. Setelah mencatat sikap negatif siswa maka guru meminta siswa untuk menuliskan perjanjian pada kolom tindak lanjut dalam jurnal dengan mencantumkan tanda tangan sebagai bukti bahwa siswa tersebut sadar akan sikap negatif yang dilakukannya dan berjanji tidak akan mengulangi perbuatan itu kembali. Sesuai dengan pernyataan Siswanto (2017: 14) yaitu penilaian harus bersifat terbuka, berarti prosedur penilaian, kriteria penilaian, dan dasar pengambilan keputusan dapat diketahui oleh pihak yang berkepentingan.

Kegiatan penilaian sikap dengan teknik observasi ini dilakukan guru terus menerus selama satu semester yaitu guru selalu membawa jurnal ketika mengajar di kelas. Hal tersebut dilakukan guru karena sikap negatif siswa muncul secara alamiah tergantung pada situasi dan kondisi yaitu secara kontekstual dan tidak bisa dipastikan kapan sikap siswa yang negatif akan timbul, oleh karena itu guru selalu siap siaga membawa jurnal sikap untuk mencatat dan melakukan penilaian apabila muncul sikap negatif siswa selama pembelajaran berlangsung. Sesuai dengan pendapat dari Ruswandi (2013:24) sikap atau tingkah laku pada manusia didasarkan pada faktor lingkungan dan mental setiap individu. Perubahan sikap yang terjadi pada manusia dapat didasari dan dibentuk tetapi dapat pula tanpa disadari akibat interaksinya saat bermasyarakat, pada umumnya perubahan sikap bersifat tidak tentu dan kontekstual.

Pelaksanaan penilaian sikap dengan teknik penilaian diri dan penilaian antar teman dilakukan oleh semua siswa pada akhir semester setelah materi pembelajaran selesai. Pelaksanaan penilaian diri dan penilaian antar teman berlangsung selama 25 menit. Pada kegiatan penilaian diri semua siswa menilai dirinya sendiri pada lembar penilaian yang sudah diberikan terkait dengan sikap spiritual dan sikap sosial siswa (jujur, disiplin, tanggung jawab, perduli, toleransi, gotong royong, dan percaya diri). Sedangakan penilaian antar teman dilakukan antar siswa yaitu siswa satu sama lain menilai sikap temanya. Agar penilaian dengan teknik antar teman berlangsung secara kondusif dan objektif maka guru menentukan secara acak setiap siswa yang akan dinilai dan yang akan menilai temanya. Hal tersebut dilakukan guru agar tidak terjadi kecurangan dan memperkecil unsur subjektifitas karena siswa merasa tidak nyaman menilai temannya.

\section{Tindak Lanjut Hasil Penilaian Sikap}

Tindak lanjut penilaian sikap dengan teknik observasi dilakukan guru Bahasa Indonesia kelas VII di SMP Negeri 1 Kota Bengkulu yaitu dengan cara guru memberikan teguran, nasehat, bimbingan dan meminta siswa membuat surat perjanjian atas sikap negatif yang dilakukannya. Kegiatan memberikan teguran, nasehat dan bimbingan dilakukan guru langsung ketika muncul sikap siswa yang negatif dan memanggil siswa keruang guru setelah kegiatan pembelajaran berlangsung untuk diberikan arahan dan 
nasehat. Jika sikap negatif siswa yang sama terjadi berulang kali maka guru melakukan tindak lanjut dengan membawa siswa kepada guru BK dan memanggil kedua orang tuanya. Sedangkan tindak lanjut untuk penilaian diri dilakukan guru dengan meminta siswa menuliskan pada selembar kertas tanggapan dan manfaat yang didapatkan siswa setelah melakukan penilaian diri. Hal tersebut dilakukan guru agar kegiatan penilaian diri yang dilakukan oleh semua siswa lebih bermakna dan siswa dapat mengambil pelajaran dari proses menilai kelebihan dan kelemahan dirinya sendiri.

Hasil penilaian sikap dengan teknik observasi berupa jurnal perkembangan sikap siswa selama satu semester diserahkan guru bahasa Indonesia kelas VII kepada wali kelas. Sejalan dengan Kemendikbud (2017:38) yang memaparkan langkah-langkah untuk membuat deskripsi nilai/perkembangan sikap selama satu semester yaitu hasil penilaian sikap dalam bentuk predikat dan deskripsi. Kemudian guru mata pelajaran melaporkan deskripsi hasil penilaian sikap yang dilakukannya baik itu dengan observasi atau jurnal maupun dengan penilaian diri dan penilaian antar teman kepada wali kelas. Guru wali kelas merumuskan nilai sikap setiap siswa ke dalam rapor berdasarkan catatan jurnal yang laporkan seluruh guru mata pelajaran. Merumuskan nilai sikap spiritual dan sosial siswa di dalam rapot dilakukan guru wali kelas dengan menggunakan aplikasi Microsoft Excel bernama Legger. Aplikasi tersebut digunakan guru untuk merekap nilai sikap siswa dengan cara guru memasukkan predikat sikap setiap siswa ( $A, B, D$ atau $D)$ ke dalam aplikasi tersebut,maka deskripsi sikap siswa akan muncul secara otomatis. Sedangkan hasil penilaian diri dan penilaian antar teman hanya dijadikan guru sebagai data konfirmasi untuk melihat pada aspek sikap apa yang menonjol dan yang masih kurang pada diri setiap siswa berdasarkan pandangan siswa sendiri dan pandangan temannya.

\section{PENUTUP}

\section{Kesimpulan}

Perencanaan penilaian sikap oleh guru dilakukan dengan mempersiapkan instrumen penilaian yaitu jurnal, lembar penilaian diri, dan lembar penilaian antarteman. Kemudian guru menjadwalkan pelaksanaan penilaian diri dan penilaian antar teman, yaitu pada akhir semester saat materi pembelajaran selesai.

Guru melakukan penilaian sikap terhadap seluruh siswa dan mencatatnya dalam jurnal dengan metode observasi saat kegiatan pembelajaran bahasa Indonesia berlangsung, yaitu secara terintegrasi dan kontekstual. Penilaian dengan cara observasi dilakukan guru terus menerus selama satu semester, kemudian guru selalu membawa jurnal sikap setiap kali akan mengajar untuk melakukan penilaian sikap dengan cara observasi. Penilaian sikap dengan teknik penilaian diri dan penilaian antar teman dilakukan siswa saat akhir pembelajaran dan diakhir semester. Kegiatan penilaian tersebut berlangsung selama kurang lebih 20 menit.

Tindak lanjut dan pengelolaan hasil penilaian sikap dengan teknik observasi dilakukan guru langsung setelah melakukan pencatatan sikap negatif siswa dalam jurnal, guru akan memberikan tindak lanjut kepada siswa berupa teguran, bimbingan, nasehat, dan membuat surat perjanjian. Sedangkan tindak lanjut penilaian sikap dengan teknik penilaian diri dan penilaian antarteman hanya digunakan guru sebagai data pendukung dan data konfirmasi sesuai dengan jurnal catatan sikap yang dimiliki guru. Pengelolaan hasil penilaian sikap dilakukan wali kelas dengan cara merumuskan nilai sikap setiap siswa diraport berdasarkan laporan jurnal dari semua guru mata pelajaran. 


\section{DAFTAR PUSTAKA}

Kemendikbud. 2017. Panduan Penilaian oleh Pendidik dan Satuan Pendidikan untuk Sekolah Menengah Pertama. Jakarta: Kemendikbud.

Kurniasih, Imas dan Berlin Sani. 2016. Revisi Kurikulum 2013 Implementasi Konsep dan Penerapan. Surabaya: Kata Pena.

Kurniasih, Imas dan Berlin Sani. 2014. Implementasi Kurikulum 2013 Konsep dan Penerapan. Surabaya: Kata Pena.

Mulyasa. 2015. Pengembangan dan Impelementasi Kurikulum 2013. Bandung : PT Remaja Rosdakarya.
Undang-Undang Republik Indonesia. No. 20 Tahun 2003 Tentang Sistem Pendidikan Nasional Pasal 1 Ayat (19).

Ruswandi. 2013. Psikologi Pembelajaran. Bandung: CV Cipta Pesona Sejahtera.

Sugiyono. 2012. Metode Penelitian Pendidikan Pendekatan Kuantitatif, Kualitatif, dan R\&D. Bandung: Alfabeta.

Sukmadinata, N. S. 2012. Metode Penelitian Pendidikan. Bandung: PT Remaja Rosdakarya Offset.

Siswanto. 2017. Penilaian dan Pengukuran (Sikap dan Hasil Belajar Peserta Didik). Klaten: Boss Script. 